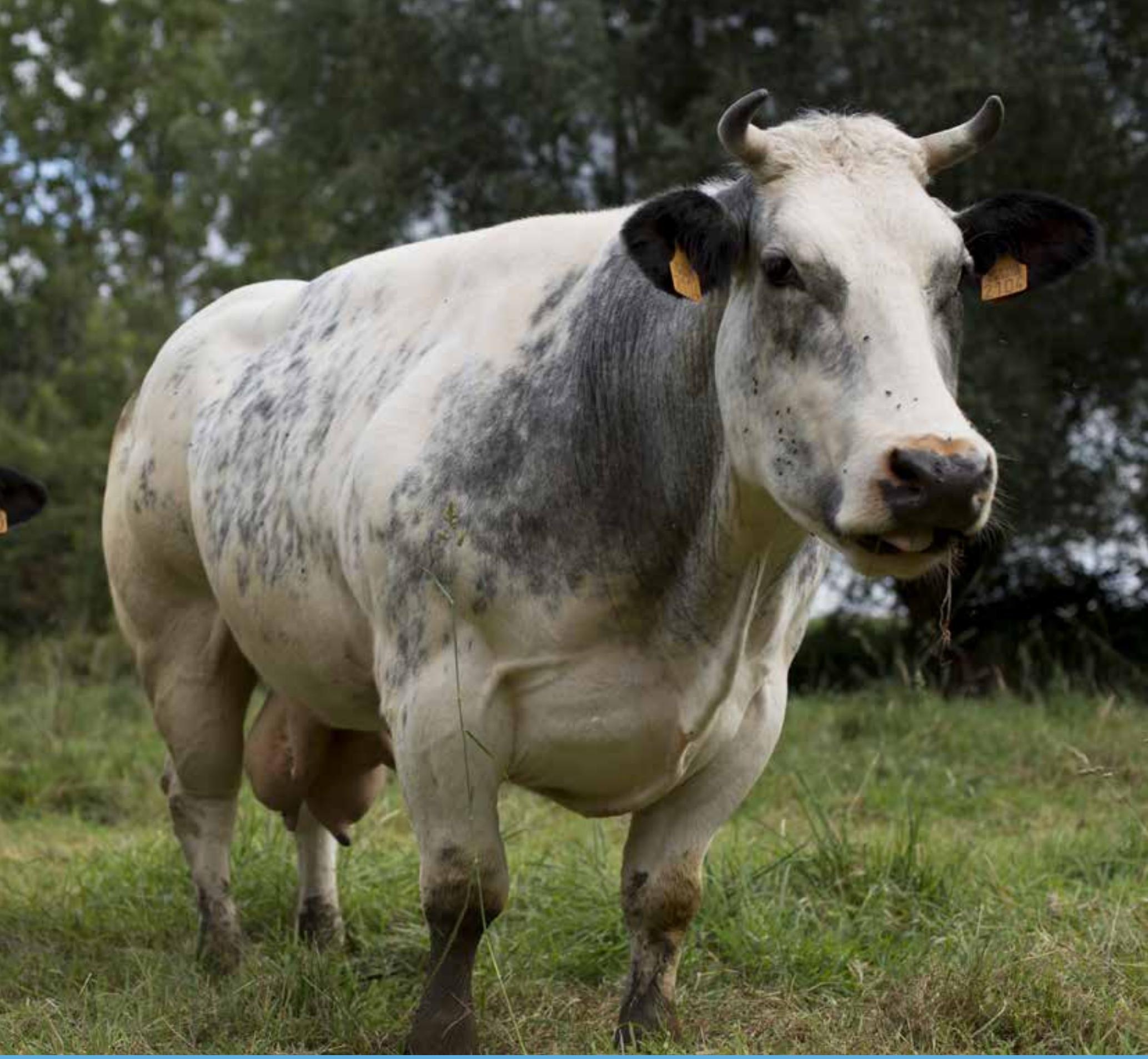

\title{
Kansen voor vleesvee
}

Willy Baltussen, Mariët van Haaster-de Winter, Nico Bondt

WAGENINGEN

UNIVERSITY \& RESEARCH 



\section{Kansen voor vleesvee}

Willy Baltussen, Mariët van Haaster-de Winter, Nico Bondt

Dit onderzoek is uitgevoerd door Wageningen Economic Research in opdracht van en gefinancierd door het ministerie van Landbouw, Natuur en Voedselkwaliteit, in het kader van het Beleidsondersteunend onderzoeksthema 'Duurzame veehouderij' (projectnummer BO-43-013.01-025)

Wageningen Economic Research

Wageningen, mei 2019

RAPPORT

2019-010

ISBN 978-94-6343-587-1 
Willy Baltussen, Mariët van Haaster-de Winter, Nico Bondt, 2019. Kansen voor vleesvee. Wageningen, Wageningen Economic Research, Rapport 2019-010. 30 blz.; 3 fig.; 6 tab.; 8 ref.

Voor de rundvleessector zijn de toekomstige kansen op een rij gezet. De sector is divers in type bedrijven, runderrassen en afzetkanalen. Voor een vitale sector is het van belang om het verhaal achter de diverse rundvleesproducten te communiceren en te gaan samenwerken in de afzet van die producten.

We have identified future opportunities for the beef sector. The sector shows a broad diversity of companies, cattle breeds and sales channels. For a vital sector, it is important to communicate the story behind the various beef products and to cooperate in the marketing of those products.

Trefwoorden: vleesvee, Nederland, concurrentiepositie

Dit rapport is gratis te downloaden op https://doi.org/10.18174/470045 of op www. wur. nl/economicresearch (onder Wageningen Economic Research publicaties).

(C) 2019 Wageningen Economic Research

Postbus 29703, 2502 LS Den Haag, T 07033583 30, E communications.ssg@wur.nl, www.wur.nl/economic-research. Wageningen Economic Research is onderdeel van Wageningen University \& Research.

\section{(cc) BY-NC}

Wageningen Economic Research hanteert voor haar rapporten een Creative Commons Naamsvermelding 3.0 Nederland licentie.

(C) Wageningen Economic Research, onderdeel van Stichting Wageningen Research, 2019

De gebruiker mag het werk kopiëren, verspreiden en doorgeven en afgeleide werken maken. Materiaal van derden waarvan in het werk gebruik is gemaakt en waarop intellectuele eigendomsrechten berusten, mogen niet zonder voorafgaande toestemming van derden gebruikt worden. De gebruiker dient bij het werk de door de maker of de licentiegever aangegeven naam te vermelden, maar niet zodanig dat de indruk gewekt wordt dat zij daarmee instemmen met het werk van de gebruiker of het gebruik van het werk. De gebruiker mag het werk niet voor commerciële doeleinden gebruiken.

Wageningen Economic Research aanvaardt geen aansprakelijkheid voor eventuele schade voortvloeiend uit het gebruik van de resultaten van dit onderzoek of de toepassing van de adviezen.

Wageningen Economic Research is ISO 9001:2008 gecertificeerd.

Wageningen Economic Research Rapport 2019-010 | Projectcode 2282100300

Foto omslag: Shutterstock 


\section{Inhoud}

$\begin{array}{ll}\text { Woord vooraf } & 5\end{array}$

$\begin{array}{ll}\text { Samenvatting } & 6\end{array}$

S.1 Belangrijkste uitkomsten $\quad 6$

S.2 Overige uitkomsten $\quad 6$

$\begin{array}{lll}\text { S.3 Methode } & 6\end{array}$

$\begin{array}{ll}\text { Summary } & 7\end{array}$

$\begin{array}{lll}\text { S.1 Key outcomes } & 7\end{array}$

$\begin{array}{lll}\text { S.2 Other outcomes } & 7\end{array}$

$\begin{array}{lll}\text { S.3 Method } & 7\end{array}$

1

$\begin{array}{ll}\text { Inleiding } & 8\end{array}$

$\begin{array}{lll}1.1 & \text { Achtergrond en doel } & 8\end{array}$

1.2 Aanpak 1.8

$\begin{array}{lll}1.3 & \text { Afbakening } & 8\end{array}$

2 De Nederlandse rundvleessector $\quad 9$

2.1 Productie $\quad 9$

2.2 Consumptie 11

2.3 Import en export $\quad 12$

2.4 Rentabiliteit $\quad 14$

2.5 Maatschappelijke thema's $\quad 15$

2.5.1 Lokale milieu $\quad 15$

2.5.2 Duurzaamheid, klimaatimpact en kringloopeconomie 16

$\begin{array}{ll}\text { 2.5.3 Diergezondheid en dierenwelzijn } & 17\end{array}$

$3 \quad$ Perspectieven voor de Nederlandse rundvleessector $\quad 18$

$\begin{array}{lll}3.1 & \text { De sector aan het woord } & 18\end{array}$

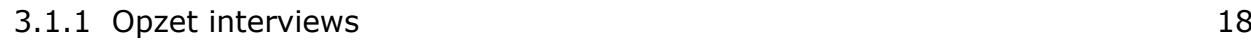

$\begin{array}{ll}3.1 .2 \text { Uitkomsten } & 18\end{array}$

$\begin{array}{ll}3.2 \text { Voorbeelden } & 20\end{array}$

3.2.1 Duurzaamheid 20

$\begin{array}{ll}3.2 .2 \text { Marktgerichte aanpak } & 21\end{array}$

$\begin{array}{ll}3.2 .3 \text { Samenwerken } & 22\end{array}$

$4 \quad$ Conclusies en aanbevelingen $\quad 23$

4.1 Conclusies $\quad 23$

4.2 Aanbevelingen 23

$\begin{array}{ll}\text { Literatuur en websites } & 26\end{array}$

$\begin{array}{lll}\text { Bijlage } 1 & \text { Runderrassen in Nederland } & 27\end{array}$ 



\section{Woord vooraf}

Op verzoek van het ministerie van LNV heeft Wageningen Economic Research onderzoek gedaan naar de kansen van vleesvee in Nederland.

Het onderzoek is begeleid door F. Vink (LNV), J. Zegers (VleesveeNL), A. Aalberts (LTO), N. Mureau (VleesveeNL en LTO) en J. Keuper (VleesveeNL). We willen hen allen danken voor de geleverde bijdragen aan dit onderzoek. Ook willen we alle vleesveehouders bedanken voor hun medewerking aan de telefonische enquête uitgevoerd door L. Dwyer.

We hopen dat de resultaten van dit onderzoek mogen bijdragen aan een duurzame en toekomstbestendige vleesveehouderij in Nederland.

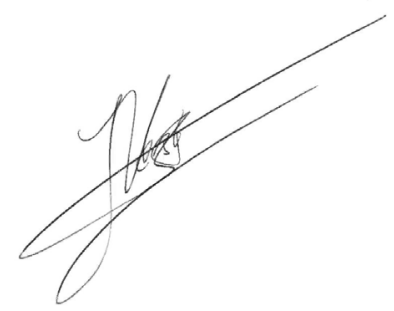

Prof.dr.ir. J.G.A.J. (Jack) van der Vorst Algemeen Directeur Social Sciences Group (SSG)

Wageningen University \& Research 


\section{Samenvatting}

\section{S.1 Belangrijkste uitkomsten}

Drie hoofdwegen kunnen onderscheiden worden om de vitaliteit van de vleessector te versterken:

- Zet in op duurzaamheid: gesloten kringlopen, onderhoud van natuur en landschap; behoud zeldzame runderrassen.

- Maak kwaliteit zichtbaar voor de consument door het verhaal achter het product te vertellen.

- Werk samen in de verwaarding van de producten.

In de praktijk zijn succesvolle voorbeelden te vinden op deze drie hoofdwegen. Zie paragraaf 4.1.

De vleesveesector moet inzetten op marktgerichtheid en samenwerking om de vitaliteit te verhogen.

Zie paragraaf 4.2 .

\section{S.2 Overige uitkomsten}

- De vleesveesector in Nederland is zeer divers met twee hoofdcategorieën namelijk het afmesten van stieren, die veelal in het buitenland geboren worden, en de zoogkoeienhouderij.

- Ook de afzet van dit vlees is divers, van huisverkoop, horeca tot supermarkten.

- De productie van vlees van vleesstieren is redelijk stabiel; het aantal zoogkoeien kent een sterk dalende tendens.

- Qua maatschappelijke thema's scoort de vleesveesector overwegend goed. Negatief is de relatief hoge impact op het klimaat vergeleken met vlees als bijproduct uit de melkveehouderij. Positief scoren dierenwelzijn, behoud van natuur en landschap en lage ammoniak- en geuremissies. Ook kan vleesvee gebruikt worden om bijproducten uit de voedingsmiddelenindustrie (die producten die niet voor humane consumptie geschikt zijn) tot waarde te brengen.

- De vleesveesector kent door de grote diversiteit een veelheid aan initiatieven om tot een vitale keten te komen. Dit varieert van internetverkoop, huisverkoop tot een convenant met supermarkten.

- De vleesveehouders willen dat hun verhaal richting de burger en de consument goed uitgedragen wordt en dat er meer samengewerkt wordt, met name om de rentabiliteit te verbeteren. Zie paragraaf 4.1 .

\section{S.3 Methode}

In dit onderzoek is inzicht gevraagd in de kansen voor de vleesveesector in Nederland, waarbij ook aandacht is voor de huidige stand van zaken. Zie paragraaf 1.1 .

Het onderzoek naar de kansen voor vleesvee is als een desk research uitgevoerd, gebaseerd op bestaande data, literatuur en publicaties. Dit is aangevuld met een beperkte hoeveelheid interviews onder vleesveehouders. Zie paragraaf 1.2. De vleesveesector is in dit onderzoek beperkt tot rundvlees van zoogkoeien, vleesstieren en vetgemeste uitgestoten melkkoeien. 


\section{Summary}

\section{S.1 Key outcomes}

We can distinguish three main tracks to enhance the vitality of the meat sector:

- Focus on sustainability: closed cycles, maintenance of nature and landscape; conservation of rare cattle breeds.

- Visualise and underline product quality for the consumer by telling the story behind the product.

- Collaborate to increase product value.

In practice, these three main tracks have some successful examples. See section 4.1.

To increase its vitality, the meat cattle sector must focus on market orientation and cooperation. See section 4.2

\section{S.2 Other outcomes}

- The meat cattle sector in the Netherlands is very diverse, with two main categories, the fattening of bulls, which are often born abroad, and suckler cow farming.

- The sale of this meat is also diverse, ranging from private sales to catering to supermarkets.

- The production of meat from beef bulls is fairly stable; the number of suckler cows is declining sharply.

- Regarding social themes, the meat cattle sector scores predominantly well. The relatively high impact on the climate, compared to meat as a by-product from dairy farming, achieved a negative score. Positive scores were recorded for animal welfare, nature and landscape conservation, and low ammonia and odour emissions. Meat cattle can also be used to add value to by-products from the food industry (those products that are not suitable for human consumption).

- Due to its great diversity, the meat cattle sector has a multitude of initiatives to achieve a vital chain, varying from internet sales and private sales to a covenant with supermarkets.

- The meat farmers want their stories to the public and the consumer to be well communicated, and they want there to be more cooperation, especially to improve profitability. See Section 4.1.

\section{S.3 Method}

This study looked for insight into the opportunities for the meat cattle sector in the Netherlands, including its current state of affairs. See Section 1.1.

The research into the opportunities for beef cattle was carried out as desk research, based on existing data, literature and publications. This has been supplemented by a limited number of interviews with meat cattle farmers. See Section 1.2. In this study, the meat cattle sector is limited to beef from suckler cows, beef bulls and fattened retired dairy cows. 


\section{$1 \quad$ Inleiding}

\subsection{Achtergrond en doel}

Diverse ontwikkelingen komen op de vleesveehouderij af. Een belangrijke ontwikkeling is dat door de veranderingen in het gemeenschappelijk landbouwbeleid de subsidies richting de vleesveehouderij sterk afgenomen zijn. De slachtpremies zijn vervangen door inkomenstoeslagen via een subsidie per hectare. Daarnaast is de belangstelling bij consumenten voor duurzame producten sterk toegenomen. ${ }^{1}$ Ook de ontwikkelingen in de melkveehouderij, zoals afschaffing melkquotum en het instellen van fosfaatrechten, hebben invloed op de ontwikkelingen in de vleesveehouderij door de plaatsingsruimte van mest en beschikbaarheid van grond en voer. Overigens speelt de instelling van de fosfaatrechten ook in de vleesveehouderij. Tegen deze achtergrond wil het ministerie van LNV inzicht hebben in de kansen voor de vleesveesector in Nederland, waarbij ook aandacht is voor de huidige stand van zaken.

\subsection{Aanpak}

Het onderzoek naar de kansen voor vleesvee is als een desk research uitgevoerd, gebaseerd op bestaande data, literatuur en publicaties. Dit is aangevuld met een beperkte hoeveelheid interviews, gehouden onder vleesveehouders. De enquêtes zijn telefonisch afgenomen in de maand december 2018, bij 16 vleesveehouders.

\subsection{Afbakening}

De vleesveesector in dit onderzoek is afgebakend tot de vleesveehouderij in Nederland waarvan het rundvlees afkomstig is uit de zogenaamde zoogkoeienhouderij inclusief het afmesten van de runderen, het afmesten van voornamelijk vleesstierkalveren die in het buitenland geboren zijn en het afmesten van uitgestoten melkkoeien (melkkoeien die vanwege productiviteit, gezondheid of ouderdom vervangen worden). Rundvlees van kalveren en rundvlees van uitstoot van melkkoeien (zonder afmesten) worden hierbij buiten beschouwing gelaten. In de openbare, gebruikte statistieken wordt dit onderscheid naar typen rundvlees niet gemaakt. Dit betekent dat vrijwel alle cijfers over de afgebakende vleesveesector schattingen betreffen.

Verder worden de volgende begrippen gehanteerd:

- Rosé en wit kalfsvlees: dieren gehouden volgens de wettelijke richtlijnen van kalfsvlees.

- Uitstoot zonder afmesten: melkkoeien die aan het eind van de productieperiode vrijwel direct geslacht worden.

- Uitstoot met afmesten: melkkoeien aan het eind van de productieperiode worden een zekere periode extra gevoerd voordat ze geslacht worden. ${ }^{2}$

- Zoogkoeien: koeien die gehouden worden voor de vleesproductie; de koeien lopen vrijwel het gehele jaar buiten en het kalf blijft bij de moeder. De stieren en de vaarzen die niet nodig zijn voor de vervanging worden veelal in een stal gevoerd tot ze het gewenste gewicht voor de slacht bereiken.

1 https://www.rijksoverheid.nl/documenten/publicaties/2017/10/03/monitor-duurzaam-voedsel-2017

2 https://heijdravleesvee.nl/dubbeldoel/ 


\section{De Nederlandse rundvleessector}

\section{$2.1 \quad$ Productie}

In Nederland worden jaarlijks ongeveer 2 miljoen runderen geslacht (COV). ${ }^{3}$ In de statistieken wordt geen onderscheid gemaakt tussen rundvleesproductie afkomstig uit de melkveestapel en van specifieke vleesrassen c.q. zoogkoeien. Specifieke statistieken bestaan hierdoor niet, waardoor alleen bij benadering de omvang van aantal gehouden runderen en van de consumptie van rundvlees aangegeven kan worden.

Ten eerste bestaat vleesvee grofweg uit drie categorieën, in volgorde van grootte:

1. vleeskalveren

2. uitstoot van melkkoeien en

3. zoogkoeien (inclusief bijbehorende kalveren) en afmesten van vleesstieren.

In deze studie richten we ons op de derde categorie, zoogkoeien en vleesstieren, maar voor de volledigheid geven we hier het overzicht van de productie. We richten ons ook op een deel van de tweede categorie, uitstoot van melkkoeien, namelijk dat deel dat na het moment van uitstoot nog verder afgemest wordt. In de statistieken is deze groep moeilijk te onderscheiden van het deel dat na de uitstoot niet afgemest wordt. Van der Peet et al. (2018) geven de kwantitatieve invulling (in aantal slachtingen per jaar) bij de drie categorieën: 1,5 miljoen vleeskalveren; 0,56 miljoen melkkoeien aan het eind van de productieperiode en 0,075 miljoen stuks vleesvee. Er zijn geen kwantitatieve gegevens over de afmest van de uitstoot van melkkoeien.

Uitgaande van $142 \mathrm{~kg}$ geslacht gewicht per vleeskalf, $260 \mathrm{~kg}$ geslacht gewicht per melkkoe en $510 \mathrm{~kg}$ geslacht gewicht per stier (bron: KWIN 2017-2018) komen we op een gewichtsverdeling van ruim 200 miljoen kg geslacht gewicht kalfsvlees, 150 miljoen kg geslacht gewicht van melkkoeien en 43 miljoen kg geslacht gewicht van zoogkoeienhouderij en vleesstierenhouderij (zie van der Peet et al., 2018).

In deze studie richten we ons op de keten die circa 43 miljoen kg geslacht gewicht aan vleesvee voortbrengt. Het betreft dan de zoogkoeienhouderij, waarbij koeien van vleesrassen na enkele keren afkalven (en zogen van het kalf) worden geslacht en de kalveren die direct afgemest worden (stieren en overtollige vrouwelijke kalveren). Ook worden er in Nederland (stier)kalveren van vleesrassen geïmporteerd die afgemest worden en geslacht worden. Het afmesten van uitgemolken koeien afkomstig van de melkveehouderij op gespecialiseerde bedrijven (soms ook vetweiden genoemd) komt nauwelijks meer voor maar wordt binnen dit onderzoek ook tot deze keten gerekend.

De vleesveehouderij is kleinschalig: zoogkoeienbedrijven hebben gemiddeld zo'n 20 volwassen dieren. In 2017 waren er 11.703 bedrijven met vleesvee (zoogkoeien en/of vleesstieren) geregistreerd, die gezamenlijk 111.000 runderen voor de vleesproductie (exclusief vleeskalveren) hadden. Daarvan waren 59.000 vrouwelijke dieren ouder dan twee jaar (zoogkoeien) en 52.000 stieren ouder dan een jaar (CBS, 2017). In tabel 2.1 en tabel 2.2 zijn respectievelijk de bedrijfsgrootteverdeling van zoogkoeienbedrijven en vleesstierbedrijven weergegeven. Uit deze tabellen blijkt dat de spreiding in bedrijfsomvang groot is in Nederland, met bijna 80\% van de bedrijven met minder dan 10 runderen. $\mathrm{Er}$ is niet onderzocht op welke type bedrijven de zoogkoeien en vleesstieren voorkomen noch is gekeken naar de leeftijd van de ondernemers.

3 https://www.cov.nl/sector-in-cijfers 
Tabel 2.1 Zoogkoeienbedrijven (aantal) naar bedrijfsomvang in 2017

$\begin{array}{rrrrr} & 1-10 \text { zoogkoeien } & 10-50 \text { zoogkoeien } & 50 \text { zoogkoeien } & \text { Totaal } \\ \text { Aantal zoogkoeienbedrijven } & 2.495 & 1.469 & 189 \quad 4.153\end{array}$

Bron: Landbouwtelling 2017.

Tabel 2.2 Vleesstierbedrijven naar bedrijfsomvang in 2017

\begin{tabular}{lrrrr} 
& $1-10$ & vleesstieren & $10-100$ vleesstieren & 100 vleesstieren \\
Aantal vleesstierbedrijven & 6.648 & 819 & 7.550 \\
\hline
\end{tabular}

Bron: Landbouwtelling 2017.

Uit figuur 2.1 blijkt dat het aantal zoogkoeien sinds 2009 ongeveer gehalveerd is, van ongeveer 120.000 naar ongeveer 60.000 runderen. Het aantal stieren ( 1 tot 2 jaar en 2 jaar en ouder) blijft in de periode 2009-2018 redelijk constant op een niveau tussen de 55.000 en 60.000 stuks $^{4}$ (zie figuur 2.1). De reden voor de teruggang in aantal zoogkoeien kan gelegen zijn in de slechte rentabiliteit, onder andere door de afschaffing van de slachtpremie en de beperkte beschikbaarheid van land voor natuurontwikkeling. De stabiele situatie in de vleesstierensector kan het gevolg zijn van een verbetering in marktgerichtheid. Onderzoek ontbreekt op dit terrein.

Zoogkoeien worden doorgaans primair gehouden voor het vlees, maar kunnen daarbij ook ingezet worden voor begrazing van natuurgebieden. In Nederland worden zoogkoeien gehouden van specifieke vleesrassen als Limousin en Charolais, Belgische Blauwe en Verbeterd Roodbont en van oorsprong Nederlandse rassen als Lakenvelder, Brandrode, Blaarkop en MRIJ. Blaarkop en MRIJ zijn dubbeldoelrassen, die zowel voor melk als vlees gehouden worden. In bijlage 1 is een overzicht gegeven van het aantal dieren dat per Nederlands runderras voorkomt. In dezelfde bijlage is een overzicht gegeven op basis van de CRV-jaarstatistieken Nederland 2017 van het totaal aantal inseminaties per vleesras. Uit dit overzicht blijkt dat de Belgisch Blauwe veel inseminaties kent (meer dan alle anderen samen) en dat er minimaal 15 vleesrassen onderscheiden worden.

Een goede beschrijving van de sector zoogkoeienhouderij en vleesstierenhouderij is moeilijk omdat statistieken ontbreken. Het aantal zoogkoeien is bijvoorbeeld vanaf 2013 niet meer bekend bij het CBS en valt onder de categorie overige koeien. Dit geldt ook voor stieren voor de vleesproductie die samen met de categorie stieren voor de fokkerij ( $>2$ jaar) ingedeeld zijn bij Stieren ( $>2$ jaar). Daarnaast worden de dieren door veehouders in een bepaalde categorie ingedeeld bij de landbouwtelling.

\footnotetext{
4 http://statline.cbs.nl/Statweb/publication/?DM =SLNL\&PA =80274NED\&D $1=a \& D 2=1,3,5,7,9,11,13,15,17, \mid \& H D R=$ G1\&STB $=T \& V W=T$
} 


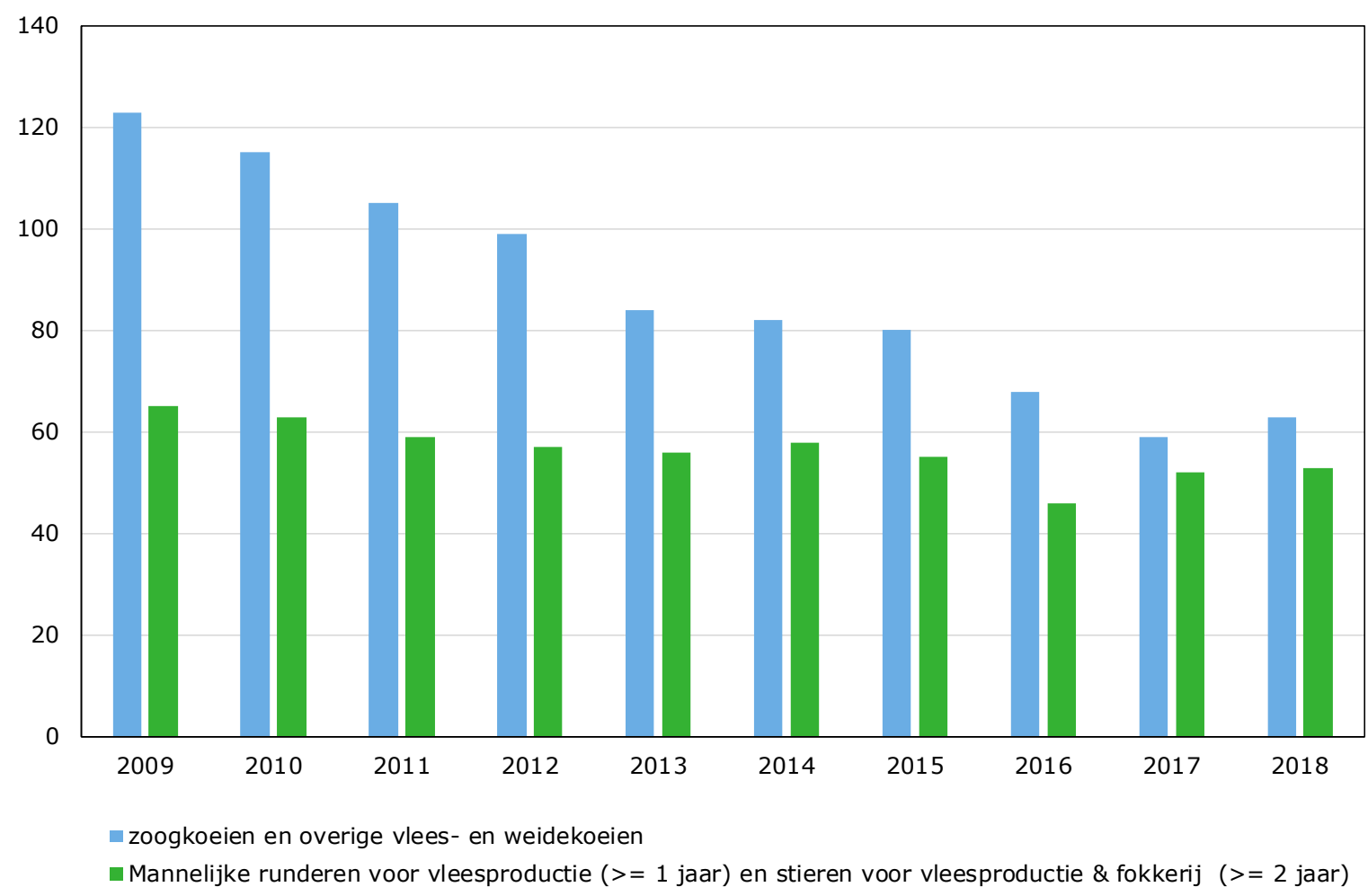

Figuur 2.1 Ontwikkeling in aantal (x 1.000) zoogkoeien en overige vlees- en weidekoeien en mannelijke runderen voor vleesproductie in de periode 2009-2018

Bron: CBS, Landbouwtelling.

\subsection{Consumptie}

In Nederland wordt circa $15 \mathrm{~kg}$ rundvlees per persoon per jaar geconsumeerd (zie Dagevos et al., 2018). Ook hier wordt in de statistieken geen onderscheid gemaakt tussen rundvlees afkomstig uit de melkveestapel en van specifieke vleesrassen c.q. zoogkoeien. Wel is duidelijk dat het consumptieniveau vrij constant in de tijd is. De door Dagevos genoemde hoeveelheid is op basis van karkasgewicht. De hoeveelheid die daadwerkelijk wordt geconsumeerd ligt ongeveer de helft lager, dus circa 7,5 kg. Uitgaande van ruim 17 miljoen inwoners is dat in totaal circa 128 miljoen $\mathrm{kg}$ rundvlees per jaar. Met een eigen productie van 195 miljoen kg rundvlees is Nederland dus ruimschoots zelfvoorzienend, en is er (zonder import) ruimte voor een export van 70 miljoen kg rundvlees. Ondanks deze positie wordt er op redelijke schaal rundvlees geïmporteerd in Nederland, denk bijvoorbeeld aan de reclame van $\mathrm{AH}$ over Iers rundvlees. Ook in andere supermarkten in Nederland wordt Iers rundvlees aangeboden. ${ }^{5}$

De door de Wereldgezondheidsorganisatie (WHO) aanbevolen hoeveelheid vleesconsumptie ligt op minder dan 500 gram per week ofwel $26 \mathrm{~kg}$ vlees per persoon per jaar. Dit geldt voor de totale vleesconsumptie, dus inclusief varken, kip en andere diersoorten. In Nederland is de totale jaarconsumptie ruim $38 \mathrm{~kg}$ vlees per persoon (77 kg karkasgewicht), dus bijna 50\% boven het WHOadvies.

Naast vlees worden in toenemende mate plantaardige vleesvervangers gegeten. De omzet van de vleesvervangers groeide van zo'n 27 miljoen euro na de eeuwwisseling naar meer dan 80 miljoen euro nu. De vleesvervangers vormen momenteel een fractie (circa $2 \%$ ) van de vleesmarkt. ${ }^{6}$ De meest recente ontwikkeling op dit vlak betreft de overname van De Vegetarische Slager door Unilever. Volgens oprichter Korteweg waren er meer gegadigden, maar hebben ze 'gekozen voor de grootst

\footnotetext{
5 https://www.irishbeef.nl/waar-te-koop/

6 Dagevos (2018) http://library.wur.nl/WebQuery/wurpubs/542467
} 
mogelijke groei. We willen over een paar jaar tien keer zo groot zijn, in plaats van vijf keer zo groot.' (nu.nl, 19 december 2018)

De aankoop van rundvlees verloopt via verschillende kanalen, namelijk: huisverkoop, slagers, supermarkten, fastfoodketens en restaurants. Om enig idee te krijgen bij de hoeveelheden rundvlees die via verschillende kanalen afgezet worden, wordt de volgende schatting gemaakt (ter vergelijking: er worden circa 75.000 vleesrunderen per jaar geslacht):

- Slager ${ }^{7}$ In Nederland zijn 1.600 winkels met een gemiddelde omzet van 600.000 euro per jaar. Er zijn minimaal 5 formules met kwaliteitsprogramma's waarvan de keurslager de grootste is met 500 winkels. Stel dat een $\mathrm{kg}$ vlees 15 euro kost, dan komt dat neer op zo' $40.000 \mathrm{~kg}$ vleesomzet per winkel per jaar. Indien $20 \%$ rund is, dan wordt er circa $8.000 \mathrm{~kg}$ rundvlees per winkel per jaar verkocht. Als alle keurslagers meedoen, heb je volgens deze berekening een omzet van 4 miljoen $\mathrm{kg}$ rundvlees per jaar. Dus dat zou neerkomen op 16.000 vleesstieren per jaar.

- Restaurants ${ }^{8}$

Er zijn 16.000 restaurants waarvan 5.000 met een Frans-Nederlandse keuken. Bij 200 dagen, 50 gasten die rundvlees eten met $0,2 \mathrm{~kg}$ portiegrootte krijg je een omzet van $2.000 \mathrm{~kg}$ per restaurant per jaar. Bij 5.000 restaurants krijg je een omzet van 10 miljoen $\mathrm{kg}$ rundvlees/ 40.000 vleesrunderen.

- Ketens zoals McDonald's ${ }^{9}$

Volgens de website van McDonald's wordt het rundvlees voornamelijk uit de melkveehouderij betrokken om een duurzaam product te leveren. Persoonlijke informatie vanuit McDonald's Nederland geeft aan dat in de toekomst waarschijnlijk nog minder rundvlees uit de vleesveekanalen aangekocht zal worden. Momenteel komt circa 30\% van het rundvlees uit Nederland, $60 \%$ uit Duitsland en een beetje uit Polen. Omzetcijfers met betrekking tot rundvlees worden niet door McDonald's vrijgegeven.

- Huisverkoop

Stel dat $5 \%$ van de 3.200 bedrijven met vleesvee huisverkoop heeft, dan zijn dat circa 150 bedrijven. Stel 100 klanten per bedrijf, die staan voor 250 consumenten, met een jaarconsumptie van $7,5 \mathrm{~kg}$ rundvlees per persoon, dan gaat het om: $150 \times 1.875=0,28$ miljoen $\mathrm{kg}$ rundvlees/1.100 vleesrunderen.

- Supermarkt

De omzet van rundvlees in 2016 en 2017 was respectievelijk 485 en 480 miljoen euro waarvan 89 en 65 miljoen euro duurzaam rundvlees was (met een keurmerk). ${ }^{10}$ Stel dat een $\mathrm{kg}$ vlees 10 euro per $\mathrm{kg}$ kost, dan is er een omzet van vers rundvlees van 48 miljoen $\mathrm{kg}$. Bief Select slacht in 2018 circa 15.000 vleesstieren van circa $525 \mathrm{~kg}$ geslacht gewicht (bijna 8 miljoen $\mathrm{kg}$ geslacht gewicht) die grotendeels afgezet wordt via supermarktketens zoals Coop, Plus, MCD Boons en Lidl.

\subsection{Import en export}

Een kenmerk van de Nederlandse rundvleesmarkt is dat er een grote import en export van rundvlees plaatsvindt. De Nederlandse export van vlees bestaat vooral uit kalfsvlees dat afgezet wordt in Frankrijk, Italië en Duitsland (zie Bakker et al., 2012 en figuur 2.3). Nederland importeert rundvlees uit de gehele wereld van Argentinië en VS tot Ierland, België en Duitsland (zie figuur 2.2). Per jaar zijn er wel schommelingen in de waarde van de import en export per land maar trendmatige ontwikkelingen in de export en import van rundvlees zijn niet te onderkennen.

\footnotetext{
7 http://detailhandel.info/index.cfm/branches/foodspeciaalzaken/slagerijen/

8 https://www. missethoreca.nl/restaurant/nieuws/2017/01/meer-restaurants-minder-cafetarias-in-2016-101256213

9 https://www.mcdonalds.nl/over-mcdonalds/kwaliteit/100-rundvlees

10 https://www.rijksoverheid.nl/documenten/publicaties/2017/10/03/monitor-duurzaam-voedsel-2017
} 


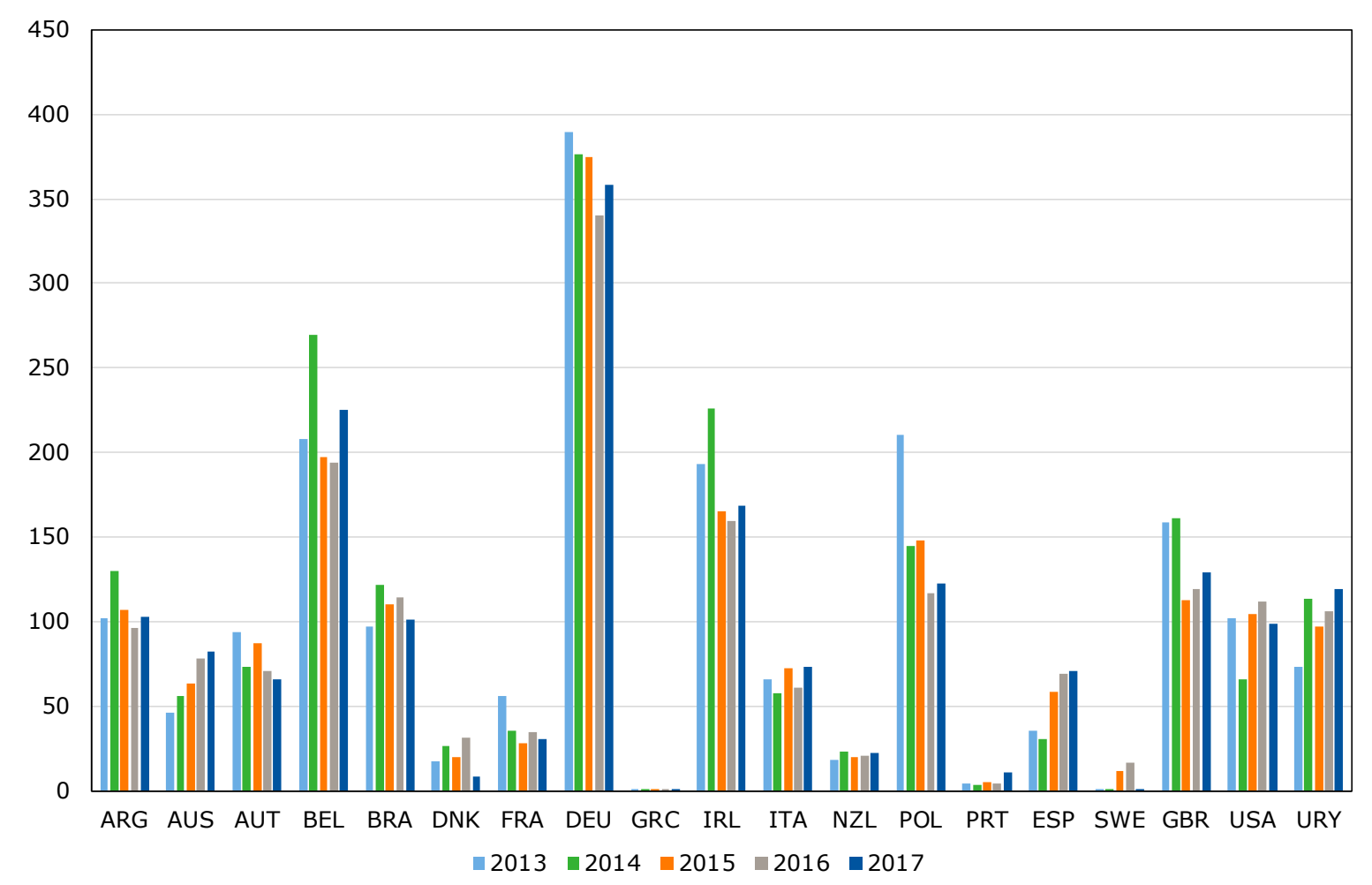

Figuur 2.2 Import van vers, gekoeld en ingevroren rundvlees in Nederland (in mln. USD) naar herkomstland in 2013-2017

Bron: Comtrade-database. Productcodes: HS 0201 (vers/gekoeld) \& 0202 (ingevroren).

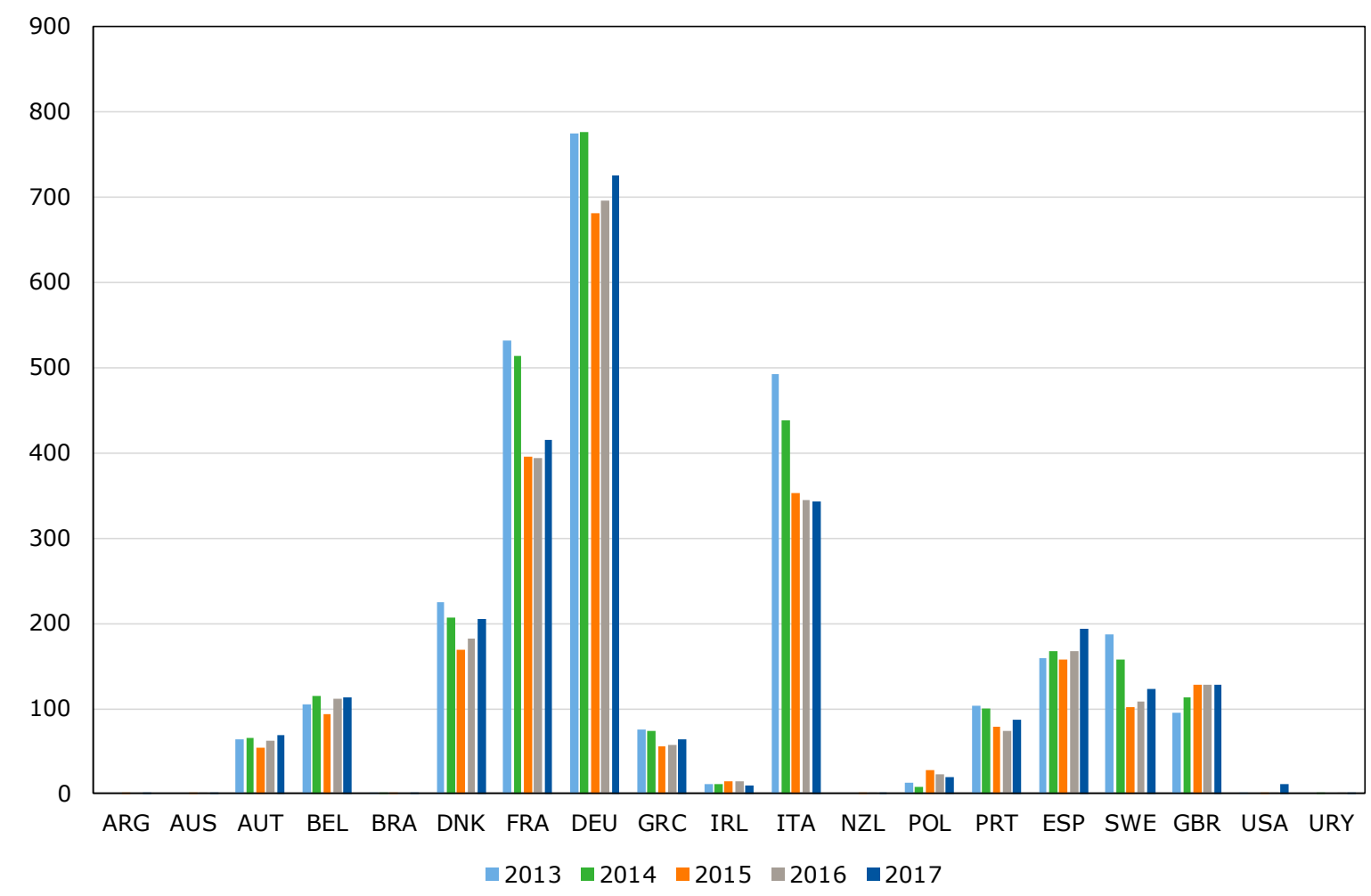

Figuur 2.3 Export van vers, gekoeld en ingevroren rundvlees uit Nederland (in mIn. USD) naar bestemmingsland in 2013-2017

Bron: Comtrade-database. Productcodes: HS 0201 (fresh/chilled) \& 0202 (frozen).

Op basis van TRACES-data is de import en export van levende runderen voor de slacht van en naar de buurlanden België en Duitsland in beeld gebracht (zie tabel 2.3 en tabel 2.4). Ook in deze statistieken 
kan geen onderscheid gemaakt worden naar kalveren, melkkoeien en vleesvee. Vanuit Nederland worden in de periode 2012-2018 jaarlijks tussen de 120.000 en 150.000 levende runderen voor de slacht geëxporteerd naar vooral België (zie tabel 2.3). De export naar België neemt toe en naar Duitsland af. 2017 is een bijzonder jaar omdat door de introductie van de fosfaatrechten veel runderen, vooral melkvee, geslacht werden. Dit is ook in de exportcijfers (stijging) als de importcijfers (daling) zichtbaar.

Tabel 2.3 Export van levende runderen voor de slacht (in aantal dieren) van Nederland naar respectievelijk België en Duitsland

\begin{tabular}{lrrrrrrr} 
& \multicolumn{5}{c}{ jaar } & 2016 & 2017 \\
\cline { 2 - 7 } export naar: & 2012 & 2013 & 2014 & 2015 & 136.739 & 131.670 \\
\hline België & 71.678 & 93.503 & 99.047 & 117.023 & 124.416 & 136.72 .82 \\
\hline Duitsland & 57.265 & 39.592 & 28.512 & 24.960 & 32.843 & 52.312 & 20.918 \\
\hline totaal & 128.943 & 133.095 & 127.559 & 141983 & 157.259 & 189.051 & 152.588 \\
\hline
\end{tabular}

Bron: NVWA.

Tabel 2.4 Import van levende runderen voor de slacht (in aantal dieren) in Nederland uit respectievelijk België en Duitsland

\begin{tabular}{lrrrrrrr} 
& \multicolumn{5}{c}{ jaar } & & \\
\cline { 2 - 7 } import uit: & 2012 & 2013 & 2014 & 2015 & 2016 & 2018 \\
België & 52.738 & 45.039 & 42.118 & 40.257 & 38.965 & 31.739 & 34.271 \\
\hline Duitsland & 17.369 & 20.800 & 21.966 & 17.760 & 18.145 & 11.278 & 10.051 \\
\hline totaal & 70.107 & 65.839 & 64.084 & 58.017 & 57.110 & 43.017 & 44.322 \\
\hline
\end{tabular}

Bron: NVWA.

De import van levende runderen voor de slacht uit België en Duitsland naar Nederland neemt af van ruim 70.000 dieren in 2012 naar ruim 44.000 dieren in 2018. De afname is het grootst uit België (zie tabel 2.4).

Op basis van inschattingen kan wel gesteld worden dat Nederland voor vers vlees, zijnde geen gehakt en geen kalfsvlees, netto importerend is. Dit blijkt ook uit het aanbod van onder andere Iers rundvlees in veel supermarkten in Nederland.

\subsection{Rentabiliteit}

Over de rentabiliteit van de bedrijven die gespecialiseerd zijn in de productie van rundveevlees in Nederland is geen openbare informatie beschikbaar. Daarom is het Bedrijveninformatienet van Wageningen Economic Research geraadpleegd. Het Informatienet is het netwerk van landbouwbedrijven waarvan Wageningen Economic Research economische, technische en milieutechnische data verzamelt en analyseert, en kent ook vleesveebedrijven. Op basis daarvan blijkt het gemiddelde saldo ${ }^{11} 481$ euro per zoogkoe (2015) op basis van 29 Informatienetbedrijven met zoogkoeien. In 2016 waren er 28 Informatienetbedrijven met gemiddeld 35 zoogkoeien en een saldo van 791 euro per zoogkoe (zie tabel 2.5). Het gemiddelde saldo in 2016 varieert van een negatief saldo van 377 euro per zoogkoe (laagste 20\%; gemiddeld 4 zoogkoeien) tot een positief saldo van 2.035 euro per zoogkoe (hoogste $20 \%$; gemiddeld 23 zoogkoeien). De $50 \%$ kleinste bedrijven heeft gemiddeld 6 zoogkoeien en een gemiddeld saldo van 600 euro per zoogkoe. De 50\% grootste bedrijven heeft gemiddeld 63 zoogkoeien en een gemiddeld saldo van ruim 840 euro per zoogkoe. Dit betekent dat er voor de $50 \%$ grootste bedrijven ongeveer 53.000 euro beschikbaar is voor de

\footnotetext{
${ }^{11}$ Het saldo wordt berekend door de opbrengsten inclusief omzet en aanwas te verminderen met de direct toegerekende kosten zoals voer en diergezondheid. Uit het saldo dienen de kosten voor grond gebouwen en eigen arbeid vergoed te worden.
} 
vergoeding van alle vaste kosten zoals grond (voor zover niet gepacht), gebouwen en arbeid. Ter vergelijking: het gemiddeld inkomen op alle landbouwbedrijven (dus niet de $50 \%$ grootste) waarbij de vergoeding voor grond en gebouwen al verrekend is, bedraagt 52.800 euro. ${ }^{12}$ De rentabiliteit van de zoogkoeienhouderij is dus laag.

Uit bovenstaande cijfers blijkt dat er tussen jaren en ook tussen bedrijven binnen jaren een enorme spreiding in financiële resultaten bestaat.

Tabel 2.5 Saldo vleesveehouderij in 2016 (in euro's per zoogkoe)

\begin{tabular}{|c|c|c|c|c|c|}
\hline & \multicolumn{5}{|c|}{ Gemiddeld saldo in 2016 in euro voor per groep } \\
\hline & $\begin{array}{r}20 \% \text { laagste } \\
\text { saldo }\end{array}$ & $\begin{array}{r}50 \% \text { laagste } \\
\text { saldo }\end{array}$ & $\begin{array}{r}50 \% \text { hoogste } \\
\text { saldo }\end{array}$ & $\begin{array}{r}20 \% \text { hoogste } \\
\text { saldo }\end{array}$ & Alle 28 bedrijven \\
\hline Gemiddeld saldo in 2016 & -377 & 600 & 840 & 2035 & 791 \\
\hline
\end{tabular}

De wijzigingen in het gemeenschappelijk landbouwbeleid kunnen daarnaast nog een invloed hebben. De subsidies zijn momenteel onafhankelijk van de productie en direct afhankelijk van de hoeveelheid grond. Voor begrazing van heide, duinen en kwelders met zoogkoeien is daarnaast een zogenoemde graasdierpremie beschikbaar, 2,3 miljoen euro in $2018,{ }^{13}$ wat lager is dan in 2017 . Uit de beschikbare informatie van RVO is niet af te leiden hoeveel subsidie in totaal naar de vleesveesector gaat.

\subsection{Maatschappelijke thema's}

Deze paragraaf geeft een overzicht van diverse maatschappelijke thema's die spelen in de vleesveehouderij. Het benoemen van deze thema's betekent in veel gevallen dat er in het maatschappelijke veld groepen zijn die van mening zijn dat effecten ongewenst zijn of juist gewenst. De meeste informatie is ontleend aan Van der Peet et al. (2018).

\subsubsection{Lokale milieu}

Zoogkoeien worden doorgaans op een potstal en in de weide gehouden. De mest uit een potstal is als droge, ruige stromest een gewenst product in de akkerbouw. Vleesstieren worden zowel gehouden in stallen met roostervloeren als in zogenaamde hellingstallen. Indien de vleesstieren op roostervloeren gehouden worden, wordt drijfmest geproduceerd. In de zogenaamde hellingstallen komt net als in de potstal droge ruige stromest beschikbaar.

Uit een potstal en hellingstal komt ammoniak vrij. Voor zoogkoeien geldt een ammoniakemissie van $4,1 \mathrm{~kg} \mathrm{NH} / \mathrm{koe} / \mathrm{jaar}$. Voor vleesstieren van 8 maanden tot 2 jaar een ammoniakemissie van 5,3 kg $\mathrm{NH}_{3} /$ dier/ jaar en vanaf 2 jaar 6,2 $\mathrm{kg} \mathrm{NH} /$ dier/jaar. Er wordt geen onderscheid gemaakt naar type stal. ${ }^{14}$ Ter vergelijking: voor een melkkoe geldt, afhankelijk van het stalsysteem, een emissie van 6 tot $13 \mathrm{~kg} / \mathrm{koe} / \mathrm{jaar}$. Zoogkoeien hebben weidegang en op die gronden kan ook mest uitgereden worden. Tijdens de weidegang zal de ammoniakemissie minimaal zijn omdat feces en urine niet bij elkaar komen. Wel kan enig nitraat naar oppervlakte- en grondwater weglekken. Er zijn geen specifieke gegevens over nitraatuitspoeling bij vleesveebedrijven.

Er zijn geuremissiefactoren op grond van de Wet geurhinder en veehouderij voor vleesstieren en vleeskalveren. Voor zoogkoeien zijn er geen geuremissiefactoren. Fijnstof speelt voor vleesvee geen rol van betekenis en geuremissies alleen voor grotere aantallen dieren die op stal gehouden worden.

\footnotetext{
12 https://www.agrimatie.nl/SectorResultaat.aspx?themaID =2272\&indicatorID =2046\&subpubID =2232\&sectorID =2243

13 https://www.rvo.nl/subsidies-regelingen/graasdierpremie

14 https://wetten.overheid.nl/BWBR0013629/2018-07-20 \#Bijlage1
} 


\subsubsection{Duurzaamheid, klimaatimpact en kringloopeconomie}

Bos (2015) heeft de vleesveehouderij qua duurzaamheid vergeleken met de intensieve veehouderij (varkens en kippen) en met vleesveehouderij in Ierland en Brazilië.

Zijn conclusies zijn:

1. 'In vergelijking met de gangbare intensieve veehouderij van vleespluimvee en varkens presteert de Nederlandse vleesveehouderij beter op het gebied van dierenwelzijn, diergezondheid, volksgezondheid, en arbeidsomstandigheden. Omgekeerd presteren de varkenshouderij en helemaal de vleespluimveehouderij per kilogram product beter op ecologische aspecten als klimaat, energie en watergebruik, en is de rentabiliteit beter. De impact van de vleesveehouderij op de nationale soortenrijkdom is in het algemeen ook groter door de hogere emissies van mineralen naar water en lucht, maar zou netto mogelijk lager kunnen zijn indien vleesveehouderij extensief is geïntegreerd in natuurbeheer.'

2. 'In de vergelijking met de productiesystemen in Ierland en Brazilië presteert de Nederlandse vleesveehouderij even goed als de Ierse productie, maar in vergelijking met Brazilië beduidend beter op aspecten als klimaat en soortenrijkdom. Deels ligt dat aan het veel hogere slachtgewicht in Nederland, en deels aan landgebruik en landconversie ${ }^{15}$ in Brazilië. Het dominante (extensieve) grassfed systeem in Brazilië presteert echter beter op dierenwelzijn, watervoorraad en waterkwaliteit. Vermoedelijk is de rentabiliteit in Brazilië ook beter, vanwege de lagere kosten van productiefactoren als grond, arbeid en huisvesting.'

Vleesrunderen zijn herkauwers en produceren daarom methaan (uit pensfermentatie), een veel sterker broeikasgas dan koolstofdioxide. Het gevolg hiervan is een relatief hoge klimaatimpact in vergelijking met andere dieren die gehouden worden voor de vleesproductie, zie tabel 2.6. In 2018 is binnen Wageningen University \& Research gestart met het meten van methaanemissies bij (melk)koeien. ${ }^{16}$ Over andere diersoorten als kalkoenen, konijnen, schapen, geiten of paarden is geen specifieke informatie bekend (Van der Peet et al., 2018).

Rundvlees uit de zoogkoeienhouderij heeft ook een veel hogere emissie in $\mathrm{CO}_{2}$-equivalenten dan rundvlees als bijproduct van de melkveehouderij. Dit komt omdat bij melkvee de totale emissie van de koe verdeeld wordt over $(7.000 \mathrm{~kg})$ melk en $(90 \mathrm{~kg})$ vlees, terwijl bij de zoogkoeienhouderij alle emissies volledig aan de vleesproductie kunnen worden toegerekend.

Moerkerken et al. (2014) geven aan dat 'de sector een eind op weg is in het reduceren van broeikasgassen'. Met betrekking tot runderen betreft het energiebesparende maatregelen en hernieuwbare energie in het algemeen, de introductie van de melkrobot (melkveehouderij) en de vervanging van melkpoeder door weipoeder (kalfsvleessector).

Tabel 2.6 Klimaatimpact (in $\mathrm{CO}_{2}$-equivalenten) per $\mathrm{kg}$ eetbare producten voor diverse vleessoorten

\begin{tabular}{lr} 
Pluimveevlees & $\mathrm{CO}_{2}$-equivalenten/kg eetbaar product \\
\hline Varkensvlees & 3,3 \\
\hline Kalfsvlees & 5 \\
\hline Rundvlees uit de zoogkoeienhouderij & 10,8 \\
\hline
\end{tabular}

Bron: https://www.rvo.nl/sites/default/files/2014/05/energie-en-klimaat-in-de-agrosectoren.pdf

Indien de runderen tijdens de afmestfase producten gevoerd krijgen die niet voor menselijke consumptie geschikt zijn, dan dragen ze bij aan het opwaarderen van voer en bijproducten (bijvoorbeeld aardappelsnippers en suikerbietenpulp) en de transitie naar kringloopeconomie. Daarbij moeten de hoeveelheden bijproducten wel beperkt blijven omdat de kringloop anders op bedrijfsniveau niet gesloten kan worden (de voer-mest-kringloop).

\footnotetext{
15 Met 'landconversie' wordt gedoeld op de omzetting van natuurgronden (met veelal grote soortenrijkdom) in landbouwgrond (veelal monoculturen).

16 https://www.wur.nl/nl/nieuws/Metingen-methaanemissie-van-vee-van-start.htm
} 
Vleesvee en met name zoogkoeien worden ingezet voor begrazing van natuurterreinen. Het weiden van vleesvee en met name zoogkoeien vindt vaak plaats in een kleinschalig landschap met permanent grasland. Er zijn geen specifieke gegevens beschikbaar over de relatie tussen de vleesveesector en het effect op de biodiversiteit, anders dan wat Bos (2015) hierover zegt: de impact van de vleesveehouderij op de nationale soortenrijkdom is in het algemeen groter in vergelijking met de gangbare intensieve veehouderij, door de hogere emissies van mineralen naar water en lucht, maar zou netto mogelijk lager kunnen zijn indien vleesveehouderij extensief is geïntegreerd in natuurbeheer. In vergelijking met rundvleesproductie in Brazilië scoort de Nederland vleesveesector beduidend beter op aspecten als klimaat en soortenrijkdom.

Voor begrazen van natuurgebieden worden vaak buitenlandse rassen van zoogkoeien gebruikt, meestal Schotse Hooglanders. Zeldzame Nederlandse rassen als Brandrode rund, Lakenvelder, Blaarkop en MRIJ kunnen goed voor begrazing van natuurgebieden gebruikt worden, maar worden daar nog niet vaak voor toegepast.

De dieren die grazen in en buiten natuurgebieden dragen bij aan het onderhoud van dat landschap. Tot slot: grazende dieren worden in een landschap gewaardeerd door Nederlanders.

\subsubsection{Diergezondheid en dierenwelzijn}

Vleesrunderen zijn gevoelig voor de meldingsplichtige dierziekten zoals mond- en klauwzeer en blauwtong. Bij vleesvee kunnen diverse virale, bacteriële en parasitaire infecties voorkomen, maar de sector staat niet bekend om specifieke gezondheidsproblemen. Het antibioticumgebruik in de vleesveesector is laag in vergelijking met andere veehouderijsectoren. De variatie tussen bedrijven is relatief hoog. ${ }^{17}$

Dierwelzijnsproblemen doen zich nauwelijks voor in de vleesveesector. De zoogkoeien lopen in de wei en het geboren kalf blijft gedurende een lange periode bij de koe. Problemen bij het krijgen van kalveren waardoor een keizersnede noodzakelijk is, doen zich voor bij twee vleesrassen, Belgische Blauwe en Verbeterd Roodbont. De fokkers van deze rassen zijn na wetenschappelijk onderzoek in overleg met de overheid in 2014 een programma gestart om in 15 tot 20 jaar de natuurlijke geboortes te verviervoudigen. In 2018 wordt dit programma voor de eerste keer geëvalueerd. Bij de overige rassen zijn nauwelijks afkalfproblemen aanwezig. De dieren in de afmestfase worden steeds vaker gehouden in ingestrooide hellingstallen met voldoende ruimte per dier. Ook worden in toenemende mate één en twee sterren Beter Leven rundvlees aangeboden, wat betekent dat de leefruimte van de dieren in de stal toeneemt. Bief Select is een voorbeeld van een grootschalig programma waar de dieren gehouden worden onder het twee sterren Beter Leven concept van de Dierenbescherming.

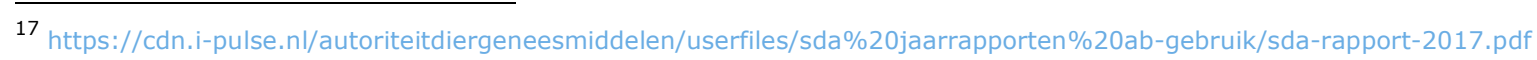




\section{Perspectieven voor de Nederlandse rundvleessector}

De informatie in het vorige hoofdstuk en aanwezige kennis waren input tijdens een expertmeeting, waarin gediscussieerd is over de toekomstperspectieven van de rundvleessector in Nederland. Op basis daarvan kunnen drie hoofdwegen onderscheiden worden om de vitaliteit van de sector te versterken naar de toekomst:

- Zet in op duurzaamheid

- Maak van marktgericht werken een automatisme

- Werk samen in de verwaarding van de producten.

Deze opties zijn teruggelegd in de sector (paragraaf 3.1) en paragraaf 3.2 geeft enkele voorbeelden hierbij.

\subsection{De sector aan het woord}

\subsubsection{Opzet interviews}

Onder 16 vleesveehouders is een telefonische enquête gehouden. De enquête behandelde vijf onderwerpen:

1. Achtergrondgegevens over type bedrijf

2. Duurzaamheid van vleesveehouderij

3. Marktgerichtheid

4. Samenwerking tussen bedrijven en in de keten

5. Noodzakelijke veranderingen op bedrijfs- en sectorniveau.

De enquêtes zijn afgenomen in december 2018. Een soortgelijke enquête was ook gepland voor runderslachterijen. Het was echter onmogelijk om in de drukke periode voor Kerst enquêtes af te nemen bij slachterijen. Dit is uiteindelijk ook niet uitgevoerd.

\subsubsection{Uitkomsten}

\section{Achtergrondgegevens bedrijven}

De 16 vleesveehouders verschillen sterk qua bedrijfsstructuur. In de eerste plaats zie je een onderscheid tussen bedrijven die zoogkoeien houden en die gespecialiseerd zijn in het afmesten van vleesstieren. Daarnaast was er één bedrijf gespecialiseerd in het afmesten van melkkoeien. Rassen die genoemd zijn: Aberdeen Angus, Branderode, Lakenvelder, Groninger Blaarkop, Blonde d'Aquitaine, Belgische Blauwe, Verbeterd Roodbond, Parthenaise, Limousin, Fleckvieh en Marchigiana, waarbij Blonde d'Aquitaine de meest voorkomende was. Ook dit geeft een beeld van de variatie binnen deze sector.

Het aantal dieren dat jaarlijks geslacht wordt varieert van minder dan 10 tot meer dan 1.000 per bedrijf. Ook qua afzet is er een grote variatie: eigen afzet via winkel of internet, aansluiting bij initiatieven zoals Bief Select en Vleesvee Integratie Twente tot afzet via een combinatie van afzetkanalen (slagers, horeca, etc.). Aansluiting bij grotere initiatieven wordt vaak gevonden bij vleesstierenhouders terwijl eigen afzet via een eigen winkel of internet vaak in combinatie met zoogkoeienhouderij plaatsvindt.

\section{Duurzaamheid}

Vrijwel alle geënquêteerde vleesveehouders zijn van mening dat ze duurzaam produceren. Het lage gebruik van antibiotica en het sluiten van kringlopen worden als sterke punten gezien. 
Men ziet wel een onderscheid tussen enerzijds de extensieve zoogkoeienbedrijven op meer marginale gronden zoals natuurgebieden, die bijdragen aan biodiversiteit en landschapsonderhoud, en de meer intensieve vleesstierenhouderij. Qua uitstoot van broeikasgassen wordt eigenlijk alleen de vergelijking met andere runderen, dan wel melkvee in Nederland dan wel vleesvee uit het buitenland, gemaakt en niet met andere diersoorten zoals pluimvee of varkens.

Ook het dierenwelzijn wordt als een heel sterk punt gezien. Afgezien van een paar vleesrassen die problemen hebben met afkalven, en een paar bedrijven die relatief veel antibiotica verbruiken, zijn er weinig welzijnsproblemen en worden veel dieren al met twee sterren Beter Leven of met het biologische label op de markt gebracht.

Veel bedrijven zijn aan het nadenken over hun mogelijkheden in een transitie naar een energieneutrale houderij. De relatieve lage behoefte aan elektriciteit door de bedrijven zelf en de lage rentabiliteit van de vleesveehouderij zijn drempels om deze stap te zetten.

\section{Marktgerichtheid}

Veel vleesveehouders noemen het lage rendement van de bedrijfstak, bijvoorbeeld: 'We hebben tig instanties waar we van alles voor moeten doen. Het is overal betalen, maar in de opbrengst gebeurt niets.' En dat terwijl de vraag naar het product doorgaans als goed ervaren wordt. De opbrengstprijzen zijn de afgelopen jaren niet verbeterd terwijl de kosten en pacht wel zijn gestegen. Veel ondernemers die niet aangesloten zijn bij een groter samenwerkingsverband zoeken naar afzetkanalen en manieren (verdienmodellen) om de vleesveehouderij rendabel te maken. Ook constateren vleesveehouders dat ze de concurrentie om grond met melkvee niet aan kunnen om financiële redenen.

Vrijwel iedereen is ervan overtuigd dat ze goed rundvlees produceren dat de concurrentie met buitenlands vlees, uit bijvoorbeeld Argentinië en Ierland, gemakkelijk aan kan. Anderen constateren wel dat het voor de consument belangrijk is dat er een constante kwaliteit aangeboden wordt. En herkennen of noemen ook andere aankoopmotieven zoals: herkomst, vertrouwen, lokaliteit, transparant, smaak. Ook vinden veel boeren dat het verhaal achter het vlees goed voor het voetlicht gebracht moet worden om een meerprijs te kunnen realiseren en zodat meer consumenten kiezen voor een transparant en kwalitatief beter product.

\section{Samenwerking tussen bedrijven en in de keten}

Het gevoel deel uit te maken van de sector wisselt tussen de geïnterviewden, van 'jazeker' tot 'nee'. In dat laatste geval voelt men zich wel eens betrokken bij een andere, specifiekere groep, vleesveehouders die anders georganiseerd zijn, bijvoorbeeld rondom een specifiek ras. Wel ervaren allen dezelfde, sectorbrede, problemen zoals stijgende kosten en schaarste van grond.

Binnen de vleesveehouderij is een grote variatie aanwezig. Velen zijn van mening dat de toekomstkansen sterk afhangen van de mate waarin ze gaan samenwerken, zoals:

'Samen gerichter dingen doen. Op eigen houtje spreek je geen grote partijen aan. Door samen dingen te doen kun je beter op dingen inspelen.'

Hoewel dit idee ook tegengesproken wordt. Men wil dan bijvoorbeeld inzetten op (groei van) thuisverkoop of zoals iemand aangeeft:

'Wij zijn niet aangesloten bij andere partijen, want mocht er iets gebeuren dan associëren ze ons daarbij. Mensen die komen kijken in de stallen, dat is de beste reclame.'

In delen van de sector wordt al sterk samengewerkt zoals Bief Select en Vleesvee Integratie Twente (VIT) laten zien. Dit zijn beiden initiatieven gestart vanuit een organisatie (vleesveehouder en slachterij) die nog steeds zelf de regie hebben en waar anderen zich bij aansluiten. In tegenstelling tot een coöperatie hebben aangesloten vleesveehouders dus geen formele inbreng in het beleid (inhoudelijk noch financieel). 
Samenwerking met terreinbeheerders is in veel gevallen een lokale aangelegenheid en speelt vooral bij de zoogkoeienhouders en veel minder bij de vleesstierhouders. Een deel van de ondernemers werkt samen met terreinbeheerders terwijl anderen weer van mening zijn dat de terreinbeheerders te veel eisen stellen. Samenwerking in de keten met slachterijen, groothandel en detailhandel komt voor bij de grotere samenwerkingsinitiatieven en ook op lokaal niveau.

Een meerderheid van de geïnterviewde vleesveehouders is niet tevreden over de huidige belangenbehartiging, via bijvoorbeeld LTO en VleesveeNL. Een terugkerende opmerking met betrekking tot LTO is dat deze organisatie meer oog zou hebben voor de melkveesector dan voor de vleesveesector. Daarnaast noemen respondenten de administratieve lasten en het ontbreken van een woordvoerder die de sector naar buiten toe vertegenwoordigt.

\section{Noodzakelijke veranderingen}

De geïnterviewde vleesveehouders zien in hoofdzaak twee belangrijke en noodzakelijke veranderingen voor hun sector. In de eerste plaats moet het verhaal over hun sector en product goed opgezet worden en goed gecommuniceerd worden met de burger en consument. Dit zijn overigens verschillende verhalen met verschillende accenten. Accenten zijn bijvoorbeeld de hoge en constante kwaliteit van het vlees (vleesstieren); de duurzaamheid (zoogkoeien); behoud van zeldzame rassen of het opwaarderen van uitgestoten melkvee. Daarnaast zijn veel van de geïnterviewde vleesveehouders van mening dat ze een echte spreekbuis missen die deze verhalen kan uitdragen.

Een tweede noodzakelijke verandering is de wens of misschien zelfs de noodzaak om samen te gaan werken. Dit samenwerken zou zich moeten concentreren op de afzet van het product. Door een gezamenlijke afzet verwacht men dat enerzijds markten bereikt kunnen worden die nu buiten hun bereik liggen, bijvoorbeeld de afzet naar (lokale) supermarkten, en anderzijds dat hogere opbrengstprijzen gerealiseerd kunnen worden waardoor de rentabiliteit zich verbetert.

\subsection{Voorbeelden}

\subsubsection{Duurzaamheid}

Duurzaam produceren is één van de uitdagingen van de rundvleessector. Innoveren op dit gebied blijft belangrijk. Hoe doen anderen dat? Een kijkje over de eigen grenzen, zie hieronder een innovatief praktijkvoorbeeld uit een andere sector: de melkveehouderij.

\section{$\mathrm{CO}_{2}$-uitstoot of ... -opslag? Door bos in de bedrijfsvoering op te nemen, word je neutraler} Het vastleggen van koolstof in de bodem biedt voordelen, zoals een vruchtbaardere en gezondere bodem en koolstof uit $\mathrm{CO}_{2}$ opslaan dat anders terechtkomt in de atmosfeer. Runderen zorgen zoals bekend voor de uitstoot van veel broeikasgassen, tegelijkertijd kan daar wat mee gedaan worden. Het gras waar zij op lopen is ook in staat om broeikasgas vast te leggen. Naast de reductie van $\mathrm{CO}_{2}$ heeft koolstofvastlegging in de bodem ook een positief effect op de uitstoot van lachgas en methaan, twee andere broeikasgassen. In 2018 is er een project van start gegaan met dit idee als uitgangspunt. ZLTO doet mee en zegt hierover: 'Via de bodem kan de land- en tuinbouw, voor de maatschappij, een bijdrage leveren aan de klimaatdoelen.' De Zeeuwse gedeputeerde De Bat noemde dat 'het project past in een duurzaam landbouwbeleid, waarbij we de productiefactoren bodem, water en biodiversiteit centraal stellen' (zeeland.nl). Melkveehouder Henk Hoefnagel is hier al eerder mee begonnen. Hij zag dat zijn bodemkwaliteit minder werd en vertelt in Veeteelt Gras (maart 2018):

'[Hoefnagel] gooide het roer om, verruilde drijfmest en kunstmest voor stalmest, bouwde een potstal en investeerde in maatregelen voor een gezondere bodem met meer organische stof. De nieuwste maatregel is het pachten van vijf hectare bos. De houtsnippers uit het bos worden gebruikt als stalstrooisel in de compoststal, wat volgens hem het welzijn van de koeien ten goede komt. De houtsnippers worden gecomposteerd in de stal. "Verse houtsnippers trekken behoorlijk stikstof uit de grond met kans op verzuring, daarom moeten ze eerst composteren. De houtsnippercompost levert vervolgens extra organische stof aan de gras- en akkerlanden van mijn bedrijf. En ik leg 
hiermee extra koolstof vast in de bodem", aldus de veehouder. Hoefnagel melkt nu 50 koeien en wil groeien naar 75 stuks. "Deskundigen zeggen dat je de uitstoot van elke tien koeien neutraliseert met een hectare bos. Met vijf hectare ben ik dus op de goede weg", zegt hij. De melkveehouder heeft goede hoop dat er in de nabije toekomst een vergoeding komt voor $\mathrm{CO}_{2}$-opslag op melkveebedrijven.' ${ }^{18}$

Soortgelijke ontwikkelingen zijn ook voor de vleesveesector denkbaar.

\subsubsection{Marktgerichte aanpak}

Zoals een geïnterviewde mooi samenvat: 'De consument bekender maken met wat we in Nederland doen en op welke manier we het doen.' In het verlengde hiervan ligt herkend worden in de markt als tegenhanger van anonimiteit. Dat gaat niet vanzelf, maar kan wel. Deze paragraaf geeft enkele voorbeelden.

Een sterk merk: De Stoerderij

Arjan Swinkels houdt 'stoere beesten', vindt hij zelf, namelijk waterbuffels, en bouwt sindsdien aan zijn eigen merk: De Stoerderij. Zijn bedrijf en nicheproducten vallen op door een marktgerichte aanpak, waarbij hij direct verkoopt aan de consument en beleving toevoegt (zowel op het bedrijf als door social media in te zetten). Ook maakt hij gebruik van crowdfunding (om vlees te verkopen) en kunnen de dieren geadopteerd worden. Jaarlijks worden er tien tot twintig buffels geslacht. Momenteel maakt het vlees de helft van de omzet uit, de rest komt van de melk(producten). (Stoerderij.nl, boerderij.nl en meatyourown.nl). In een interview in Valkverrast zegt hij zelf met betrekking tot zijn motivatie:

'Ik heb gestudeerd en als consultant gewerkt bij een wervings- en selectiebureau. Maar tijdens een werkvakantie bij jonge geitenboeren in Frankrijk zag ik dat je ook een mooi leven kon opbouwen met een bescheiden veestapel en in samenhang met de natuur. Dat verblijf op de Franse boerderij is mijn grote inspiratiebron geweest. Ik heb het kantoor vaarwel gezegd en voor het boerenleven gekozen.'

Over consumenten en hun waardering voor eerlijk en duurzaam geproduceerd voedsel zegt hij vervolgens:

'Mensen willen de herkomst ervan kennen en zijn ook stukje bij beetje meer bereid om wat meer te betalen voor bijzondere en met liefde gemaakte producten. En het romantische tintje dat kleine boeren als ik aan onze inspanningen geven, spreekt velen natuurlijk aan. Niet iedere boer hoeft een grote tractor en is bezig met schaalvergroting, met stallen voor duizend kippen, koeien of varkens. Het kan ook anders. ${ }^{\prime 19}$

\section{Wildernisvlees}

FREE Nature (Foundation for Restoring European Ecosystems) biedt vlees aan van dieren die hun hele leven in de vrije natuur hebben doorgebracht onder de vlag 'wildernisvlees'. ${ }^{20}$ De basis is het beheer van natuurgebieden met 1.500 vrij levende grote grazers. Zij stellen graasdieren beschikbaar voor natuurbeheer en ontvangen daar een vergoeding voor en ontvangen de opbrengst van het vlees. Met personeel en vrijwilligers wordt dit uitgevoerd. Men heeft 18 afhaalpunten vooral in Midden-Nederland en één in Zuid-Limburg.

\section{Groninger Blaarkoppen}

Uit onderzoek van Wageningen University \& Research uit 2010 wordt het volgende geconcludeerd: ${ }^{21}$

\footnotetext{
${ }^{18}$ In Oostenrijk wordt al betaald voor $\mathrm{CO}_{2}$-vastlegging, gemiddeld 300 euro per hectare. Geen subsidies door de overheid, maar bedrijven betalen middels certificaten. $\mathrm{Er}$ is daar inmiddels een wachtlijst aan bedrijven die $\mathrm{CO}_{2}$-certificaten willen vastleggen via boeren.

19 https://www.valkverrast.nl/publicaties/knuffel-de-buffel en https://www. youtube.com/watch?v=gbb18HRNpnM

20 https://www. freenature.nl/wildernisvlees/kwaliteit-en-eisen

21 https://zeldzamerassen.nl/blaarkopnet/wp-content/uploads/sites/11/2014/07/BiocomKruidenierRapport.pdf
} 
'Samengevat komt de blaarkop tegemoet aan veel wensen van boeren, burgers en buitenlui, evenals die van de consument en overheid, op het gebied van duurzaamheid en maatschappelijk verantwoord ondernemen. Bovendien heeft de blaarkop de potentie om natuur, landschap, veehouderij en burger/consument op een goede manier met elkaar te verbinden. Daarmee is de blaarkop veel meer dan enkel een koe met een dubbeldoel; de blaarkop biedt de Kruidenier Groep en haar ketenpartners perspectief in moderne tijden, in het bijzonder voor veehouders met een bedrijfsvoering die gericht is op natuurbeheer en/of multifunctionele landbouw. Een belangrijke voorwaarde daarbij is een ontwikkeling van een renderend businessmodel.'

Anno 2018 lijkt nog geen renderend businessmodel gerealiseerd te zijn, maar het bestand aan Groninger Blaarkoppen neemt iets toe (zie bijlage 1) en het vlees van blaarkoppen wordt middels diverse (boerderij)winkels, offline en online, verkocht. ${ }^{22}$

\subsubsection{Samenwerken}

Over hoe de wens of misschien zelfs de noodzaak om samen te gaan werken vorm krijgt bij anderen, kan in deze paragraaf worden gelezen.

\section{Natuurvlees en Emté}

Natuurvlees is afkomstig van runderen die grazen in Nederlandse natuurgebieden, natuurparken, bossen, polders en uiterwaarden. Door te grazen in de vrije natuur, helpen de runderen mee om natuurgebieden te behouden. Ze houden de natuur open en geven de ruimte aan allerlei plantensoorten die anders in de verdrukking zouden komen. De koeienmest houdt de grond vruchtbaar.

Inmiddels zijn er al zo'n 70 Nederlandse boeren die Natuurvlees leveren, dat door supermarkt Emté verkocht wordt. Ze werken samen aan de kwaliteit van het vlees en het welzijn van de runderen. Ze controleren voortdurend de leefomstandigheden en het voedsel. ${ }^{23}$ Natuurvlees is ook een voorbeeld van marktgerichte aanpak waarbij het vlees onder een merk en met een verhaal bij Emté wordt aangeboden aan consument.

\section{Bief Select en supermarkten}

Circa 100 vleesveehouders hebben zich verenigd onder de vlag van Bief Select om een product aan te bieden voor supermarkten. Zij produceren jaarlijks circa 15.000 vleesstieren die als kalf in Frankrijk aangekocht worden en in Nederland onder het twee sterren Beter Leven Kenmerk van de Dierenbescherming afgemest worden. Enkele duurzaamheidsaspecten die hoog in het vaandel staan zijn kwaliteit van het vlees op basis van ras (Blonde d'Aquitaine) en voeding, dierenwelzijn (Beter Leven kenmerk), duurzaamheid (recyclen van mest en voer door gebruik potstallen en ruige mest); antibiotica vrij en maatschappelijk verantwoord door een lage $\mathrm{CO}_{2}$-footprint in vergelijking met vlees uit andere landen.

Vlees van Bief Select is onder andere te verkrijgen bij Coop, Plus, MCD Boons en Lidl, met een hogere opbrengstprijs voor de vleesveehouders.

22 http://blaarkopwinkel.nl/Blaarkop\%20vlees\%20aankoop\%20informatie
23 https://www.emte.nl/assortiment/bewuste-keuze/natuurvlees.htm 


\section{$4 \quad$ Conclusies en aanbevelingen}

\subsection{Conclusies}

Dit hoofdstuk geeft de conclusies van het onderzoek weer aan de hand van de onderzoeksvraag naar de kansen voor de vleesveesector in Nederland, waarbij ook aandacht is voor de huidige stand van zaken.

Hoe ziet de huidige vleesveesector eruit?

- De vleesveesector in Nederland is kleinschalig en zeer divers met twee hoofdcategorieën namelijk het afmesten van stieren, die veelal in het buitenland geboren worden, en de zoogkoeienhouderij.

- Zoogkoeien worden doorgaans primair gehouden voor het vlees, maar kunnen daarbij ook ingezet worden voor begrazing van natuurgebieden. In Nederland worden zoogkoeien gehouden van specifieke vleesrassen en van oorspronkelijk Nederlandse rassen; de diversiteit is in de praktijk (lees: interviews) groot.

- De productie van vlees van vleesstieren is redelijk stabiel; het aantal zoogkoeien kent een sterk dalende tendens. Onduidelijk is of hier een causaal verband is met de mate van samenwerking tussen vleesveehouders en ketenpartijen, die duidelijk groter is bij vleesstierenhouders dan bij zoogkoeienhouders.

- In Nederland wordt circa $15 \mathrm{~kg}$ rundvlees (in totaal) per persoon per jaar geconsumeerd, en dit is redelijk constant in de tijd. Rundvlees wordt gekocht in boerderijwinkels, via internet, in de horeca, bij slagers en in de supermarkt.

- Qua maatschappelijke thema's scoort de vleesveesector overwegend goed. Negatief is de relatief hoge impact op het klimaat, zeker vergeleken met vlees uit de melkveehouderij. Deze sector laat zien dat het mogelijk is de impact op het klimaat te beperken. Positief scoort de sector op dierenwelzijn, behoud van natuur en landschap en lage ammoniak- en geuremissies. Ook kan vleesvee gebruikt worden om bijproducten uit de voedingsmiddelenindustrie tot waarde te brengen doordat ze tijdens de afmestfase producten gevoerd krijgen die niet voor menselijke consumptie geschikt zijn.

- De vleesveesector kent door de grote diversiteit ook een veelheid aan initiatieven om tot een vitale keten te komen. Dit varieert nu van huisverkoop in vooral de zoogkoeienhouderij tot een convenant met supermarkten in de vleesstierenhouderij.

- De vleesveehouders willen dat hun verhaal richting de burger en de consument goed uitgedragen wordt en dat er meer samengewerkt wordt met name om de rentabiliteit te verbeteren. Een deel van de vleesveehouders wil het verhaal ondersteunen met een onafhankelijk keurmerk voor rundvlees uit Nederland.

- Drie hoofdwegen kunnen onderscheiden worden om de vitaliteit van de sector te versterken naar de toekomst:

- Zet in op duurzaamheid.

- Maak van marktgericht werken een automatisme.

- Werk samen in de verwaarding van de producten.

\subsection{Aanbevelingen}

Aanbevelingen voor een vitale vleesveesector zijn op te delen naar verduurzaming, een meer marktgerichte benadering en het uitbreiden van de onderlinge samenwerking.

Verdere verduurzaming

Verdere verduurzaming van de productie is één van de uitdagingen van de rundvleessector. Maar pak die handschoen op. Verduurzaming negeren ondermijnt het bestaansrecht van de sector op termijn. 


\section{Zet de troefkaart in}

Negatief is de relatief hoge impact van rundvleesproductie op het klimaat, zeker vergeleken met vlees uit de melkveehouderij. Dat kan niet veranderd worden omdat het inherent is aan het dier - een herkauwer - maar het kan wel beperkt worden door maatregelen te treffen. Wat is er bijvoorbeeld mogelijk qua aanpassing van de pensfermentatie door rantsoenwijzigingen of fokkerij? Maar positief scoort de sector op dierenwelzijn, behoud van natuur en landschap en lage ammoniak- en geuremissies. Ook kan vleesvee gebruikt worden om bijproducten uit de voedingsmiddelenindustrie tot waarde te brengen. Benut die aspecten en vergroot de impact ervan. Zoek nieuwe manieren om de impact te beperken. Wat is er mogelijk qua gesloten kringlopen, onderhoud van natuur en landschap, behoud van zeldzame runderrassen?

\section{Marktgericht werken}

Een goed product verkoopt zichzelf niet, maar een goed product is wel een basisvoorwaarde. Daarvoor is een focus op de klant, de vraagkant van de markt nodig. Zij kopen immers waar zij behoefte aan hebben en dat hoeft niet per se hetzelfde te zijn als wat jij verkoopt. De uitdaging is daarom om consumenten jouw product te laten kopen. Dit leidt tot de volgende aanbevelingen:

\section{- Duw niet blind iets de markt in}

Verkoop niet alleen een goed product, maar vervul zo veel mogelijk de behoeften van consumenten. Begrijp hun behoeften en wensen. Consumenten kopen bijvoorbeeld steeds meer duurzame producten, waarderen transparantie en hebben een duidelijke voorkeur voor vers vlees. En zo zijn er meer. Zoek uit wat jouw consumenten willen en pas, indien nodig, het product en de afzet aan.

\section{- Kom uit de anonimiteit}

$\mathrm{Ga}$ in gesprek met de consument en ontwikkel een helder en herkenbaar verhaal. Houd ruimte voor personalisatie. Immers, de sector is veelzijdig. De verschillen tussen bedrijven zijn vaak groot, bijvoorbeeld qua type bedrijf en met welk doel het vleesvee gehouden wordt. Erken de diversiteit van de sector, en maak er gebruik van. Er zijn dus meerdere verhalen waarbij het minder van belang is of het ene verhaal beter is dan het andere, zolang ze voor consumenten maar aansprekend zijn - en je je ermee onderscheidt in de markt.

\section{- Bied meer dan een product: een ervaring}

'De beste dingen in het leven zijn geen dingen (maar momenten).' Dit constateerden ook Pine en Gilmore (2009). Zij stellen dat we in een tijd leven waarin niet meer het product of de kwaliteit het belangrijkste verkoopcriterium is maar authenticiteit en het bieden van een beleving. De vleesveesector heeft wat dit betreft een uitstekende startpositie, die uitgebouwd kan worden. Verkoop niet alleen één pond rundergehakt, maar bouw er een ervaring omheen en laat de consument zich verbonden voelen met je bedrijf.

\section{- Brede blik (voor- en achterwaarts)}

In een marktgerichte benadering staat de consument centraal en de consument vormt het uitgangspunt voor ontwikkeling van het product. Immers, een consument koopt wat hij wil, niet wat iemand probeert te verkopen. Deze focus op de eindklant vergt een bredere blik dan op de volgende of vorige schakel en het delen van informatie. Een mooie eerste stap kan zijn, zoals één van de geïnterviewden stelt: 'Er moet betere communicatie zijn tussen de mester, slachterijen en uitsnijderijen.'

\section{- Denk na over je businessmodel}

Maak het jezelf makkelijk door het hebben van overzicht en focus. Het nadenken over je businessmodel kan hierbij helpen. Dit beschrijft in de basis hoe een bedrijf waarde creëert, levert en behoudt. Je krijgt helderheid in waar je als bedrijf voor staat, inclusief sterke, zwakke kanten en knelpunten en aspecten die cruciaal zijn om succesvoller te worden. Bijvoorbeeld of een samenwerking met één of meerdere partijen wel of geen goed idee is. 


\section{Samenwerken}

Om toegang tot de markt te behouden of verkrijgen is het aanbevelingswaardig om samen te werken. Ook kan op die manier vaker tegemoetgekomen worden aan de behoefte van continue levering en adequate borging van de kwaliteit van producten. Een professionele markt vraagt daarom.

Bij het samenwerken wordt het volgende aanbevolen:

- Zoek de samenwerking op, en kies of maak de samenwerkingsvorm die bij jou en je groep past, ook qua ondernemersstijl. Samenwerken betekent ook dat je een deel van de beslissingen uit handen geeft.

- Samenwerking is noodzakelijk om een zeer hoge en uniforme kwaliteit te realiseren (en te borgen), en om een voldoende en constante aanvoer te krijgen, zoals die door vrijwel alle afnemers geëist wordt. Door samen te werken werk je aan een betere positie of toegang tot de markt, waardoor je überhaupt kunt afzetten, en de afzetmarkt wellicht ook substantieel vergroot kan worden. Samenwerken kan in diverse vormen. Privaat of een gezamenlijk initiatief. Voor samenwerking tussen vleesveehouders is het mogelijk om een producentenorganisatie op te richten die voor de gezamenlijk afzet zorgdraagt. De wettelijke mogelijkheden zijn volop aanwezig. ${ }^{24}$ Door een producentenorganisatie op te richten, te laten erkennen en de activiteiten helder te benoemen ontstaan er geen problemen met de Mededingingswet. Ondernemers kunnen dan gezamenlijk afspraken maken, maar leveren ook een deel van hun beslissingsvrijheid in. Ook is het mogelijk om een Unie van producentenorganisaties te vormen die weer een aantal taken voor de producentenorganisaties voor haar rekening neemt. ${ }^{25}$ Het vormen van een brancheorganisatie lijkt op het eerste oog weinig voordelen te bieden gezien de diversiteit in de verschillende schakels van de keten. De huidige initiatieven Bief Select en Vleesvee Integratie Twente zijn voorbeelden die door een ondernemer tot stand gebracht zijn en niet door onderlinge samenwerking van vleesveehouders of door samenwerking met partijen in de keten.

Het uiteindelijke resultaat van de samenwerking wordt bepaald door de dynamiek tussen de 'harde' en de 'zachte' aspecten. Onder vertrouwen (zacht aspect) valt bijvoorbeeld sfeer, waarden en conflict. Als er vertrouwen is, heeft dat een positieve invloed op de samenwerking en daarmee op het beoogde resultaat. Het hebben van gemeenschappelijke doelen en heldere verantwoordelijkheden zijn voorbeelden van harde aspecten.

- De wens voor betere prijzen is begrijpelijk. Samenwerken heeft veel voordelen, maar leidt theoretisch gezien niet altijd direct tot betere prijzen. ${ }^{22}$ Een prijsverbetering is vooral haalbaar als je een uniek product op de markt kunt brengen, waar vraag naar is. Of indien er een situatie ontstaat waarbij het falen van de markt tegengegaan wordt, bijvoorbeeld als tegengewicht tegen de macht van supermarkten. Samenwerken blijkt ook te leiden tot meer contacten in de sector, ontsluiting van expertkennis, opdoen van innovatieve ideeën en informatiedeling. Hierdoor kan efficiënter geproduceerd worden en op kosten bespaard worden. ${ }^{22}$

\footnotetext{
${ }_{25}^{24}$ Zie publicatie "Positie primaire producent in de keten; Samenwerking en prijsvorming" http://edepot.wur. nl/452740 25 https://zoek. officielebekendmakingen.nl/stcrt-2014-29371.html
} 


\section{Literatuur en websites}

Bakker, T., W.H.M. Baltussen en R.B. Doorneweert, 2012. Concurrentiemonitor blank kalfsvlees. Den Haag: LEI, (LEI-rapport: Onderzoeksveld Markt \& ketens)

Bos, A.P., 2015. De relatieve duurzaamheid van de Nederlandse roodvleessector. Een kwalitatieve vergelijking. Wageningen, Wageningen UR (University \& Research centre) Livestock Research, Livestock Research Rapport 841, 68 blz.

Dagevos, H., D. Verhoog, P. van Horne en R. Hoste, 2018. Vleesconsumptie per hoofd van de bevolking in Nederland, 2005-2017 Wageningen Economic Research (Wageningen Economic Research nota 2018-108) - 9 http://library. wur. nl/WebQuery/wurpubs/543620

KWIN 2017-2018; Blanken, K., F. de Buisonje, A. Evers, W. Ouweltjes, J. Verkaik, I. Vermeij en H. Wemmenhove, Kwantitatieve Informatie Veehouderij 2017-2018, September 2017, Handboek 33

Linker, P.J., 2008. Het sturen van netwerken en ketens. Voorwaarden voor optimalisatie. Overheidsmanagement (11), 20-23.

Moerkerken, A., T. Gerlagh, G. de Jong en A.D. Verhoog (2014). Energie en klimaat in de Agrosectoren. Utrecht : Rijksdienst voor Ondernemend Nederland. Publicatienummer: 2AGRO1406

Pine, J. en J.H. Gilmore, 2009. De beleveniseconomie. Academic Service

Peet, G. van der, F. Leenstra, I. Vermeij, N. Bondt, L. Puister en J. van Os, 2018. Feiten en cijfers over de Nederlandse veehouderijsectoren 2018. Wageningen Livestock Research Rapport 1134 https://doi.org/10.18174/464128

Statistics for beef and veal 2015 THE DANISH LIVESTOCK AND MEAT BOARD 


\section{Bijlage 1 Runderrassen in Nederland}

Tabel B1.1 Aantal raszuivere (>87\%) volwassen vrouwelijke stamboekrunderen per Nederlands runderras in de tijd (Witrik is geen ras, kleurslag)

\begin{tabular}{|c|c|c|c|c|c|c|c|c|}
\hline $\begin{array}{l}\text { Nederlandse } \\
\text { runderrassen }\end{array}$ & & $\begin{array}{l}\text { verwachting } \\
\text { einde } 2018\end{array}$ & Dec-17 & 2016 a) & 2014 & $\begin{array}{r}2007- \\
2008\end{array}$ & $\begin{array}{r}2002 \\
\text { (landen- } \\
\text { rapport) }\end{array}$ & $\begin{array}{r}1975- \\
1977\end{array}$ \\
\hline Brandrood rund & Deep red cattle & $\begin{array}{l}\text { geen info van } \\
\text { stamboek }\end{array}$ & 1.216 & 1.150 & 941 & 454 & 100 & \\
\hline $\begin{array}{l}\text { Fries Hollands vee } \\
\text { (zwartbont) }\end{array}$ & $\begin{array}{l}\text { Dutch Friesian } \\
\text { cattle }\end{array}$ & $\begin{array}{l}\text { geen info van } \\
\text { stamboek }\end{array}$ & 2.131 & 2.129 & 1.621 & 3.500 & 5.632 & 926.956 \\
\hline Groninger blaarkop & $\begin{array}{l}\text { Groningen White } \\
\text { Headed cattle }\end{array}$ & licht stijgend & 1.658 & 1.603 & 2.190 & 2.366 & 2.165 & 21.272 \\
\hline Holstein zwartbont & Holstein Friesian & licht stijgend & 975.911 & & & 985.318 & 1.282 .025 & \\
\hline Holstein roodbont & Holstein Friesian & licht stijgend & 211.519 & & & 153.330 & & \\
\hline Lakenvelder & $\begin{array}{l}\text { Dutch Belted } \\
\text { cattle; Black and } \\
\text { White; Red and } \\
\text { White }\end{array}$ & $\begin{array}{l}\text { geen info van } \\
\text { stamboek }\end{array}$ & 2.000 & 2.685 & 1.200 & 1.200 & 1.700 & \\
\hline $\begin{array}{l}\text { MRIJ (Maas-Rijn- } \\
\text { IJsselvee) }\end{array}$ & $\begin{array}{l}\text { Meuse-Rhine- } \\
\text { Yssel cattle }\end{array}$ & vrijwel stabiel & 10.773 & 12.113 & 15.567 & 17.335 & 18.339 & 345.338 \\
\hline Roodbont Fries vee & $\begin{array}{l}\text { Friesian Red and } \\
\text { White cattle }\end{array}$ & $\begin{array}{l}\text { geen info van } \\
\text { stamboek }\end{array}$ & 340 & 388 & & 200 & 119 & 3.834 \\
\hline Verbeterd Roodbont & $\begin{array}{l}\text { Improved Red } \\
\text { and White cattle } \\
\text { (beef breed) }\end{array}$ & vrijwel stabiel & 679 & 707 & 1.052 & 945 & 1.260 & \\
\hline
\end{tabular}

a) In 2016 zijn aantallen volwassen vrouwelijke dieren voor Lakenvelder en Roodbont Fries vee geschat op basis van $20 \%$ jongvee. 
Tabel B1.2 Totaal aantal inseminaties per jaar per vleesras

\begin{tabular}{|c|c|c|c|c|c|}
\hline \multirow[t]{2}{*}{ Vleesras } & \multicolumn{5}{|c|}{ Totaal inseminaties per jaar } \\
\hline & 2017 & 2016 & 2015 & 2104 & 2013 \\
\hline Aberdeen Angus & 1.632 & 409 & 271 & 227 & 184 \\
\hline Belgische Blauwe & 803.565 & 656.178 & 427.542 & 301.117 & 249.516 \\
\hline Buffel & 12 & 60 & 5 & 9 & 16 \\
\hline Dexter & 56 & 44 & 66 & 45 & 72 \\
\hline Hereford & 505 & 615 & 430 & 389 & 392 \\
\hline Limousin & 553 & 679 & 750 & 918 & 1.072 \\
\hline Maine Anjou & 69 & 82 & 150 & 167 & 161 \\
\hline Speckle Park & 140 & 29 & - & - & - \\
\hline Verbeterd Roodbont & 2.306 & 3.018 & 3.221 & 3.753 & 4.023 \\
\hline Wagyu & 166 & 200 & 189 & 267 & 202 \\
\hline Overig/onbekend & 77 & 84 & 80 & 50 & 91 \\
\hline
\end{tabular}

Bron: CRV-jaarstatistieken Nederland 2017; tabel 14. In tabel 17 van CRV-jaarstatistieken Nederland 2017 blijkt dat het percentage vleesstieren van het totaal aantal eerste inseminaties in de loop van de jaren sterk varieert van circa $5 \%$ in 1997 tot meer dan $21 \%$ in 2017 . 
Wageningen Economic Research Postbus 29703

2502 LS Den Haag

T 0703358330

Ecommunications.ssg@wur.nl

www.wur.nl/economic-research

Wageningen Economic Research RAPPORT

2019-010
De missie van Wageningen University \& Research is 'To explore the potential of nature to improve the quality of life'. Binnen Wageningen University \& Research bundelen Wageningen University en gespecialiseerde onderzoeksinstituten van Stichting Wageningen Research hun krachten om bij te dragen aan de oplossing van belangrijke vragen in het domein van gezonde voeding en leefomgeving. Met ongeveer 30 vestigingen, 5.000 medewerkers en 10.000 studenten behoort Wageningen University \& Research wereldwijd tot de aansprekende kennisinstellingen binnen haar domein. De integrale benadering van de vraagstukken en de samenwerking tussen verschillende disciplines vormen het hart van de unieke Wageningen aanpak. 


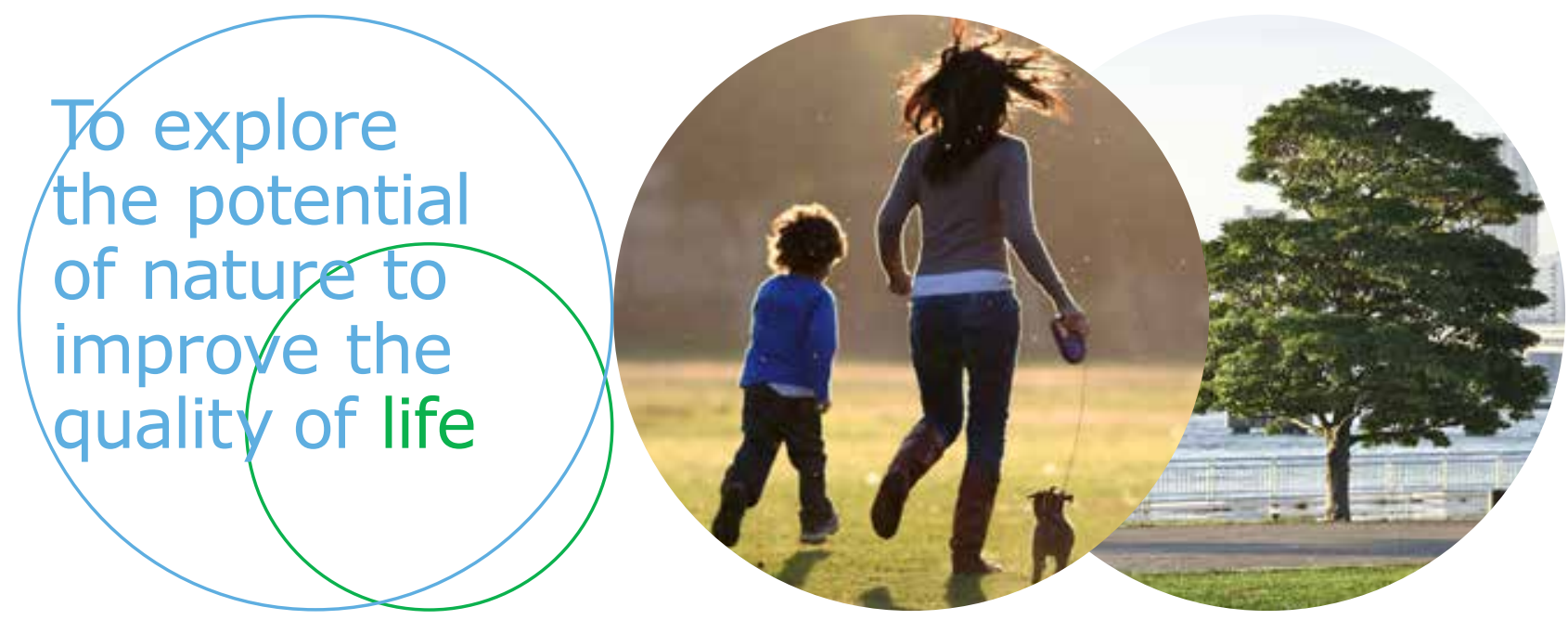

Wageningen Economic Research Postbus 29703

2502 LS Den Haag

E communications.ssg@wur.nl

$T+31(0) 703358330$

www.wur.nl/economic-research

De missie van Wageningen University \& Research is 'To explore the potential of nature to improve the quality of life'. Binnen Wageningen University \& Research bundelen Wageningen University en gespecialiseerde onderzoeksinstituten van Stichting Wageningen Research hun krachten om bij te dragen aan de oplossing van belangrijke vragen in het domein van gezonde voeding en leefomgeving. Met ongeveer 30 vestigingen, 5.000 medewerkers en 10.000 studenten behoort Wageningen University \& Research wereldwijd tot de aansprekende kennis-

Rapport 2019-010

ISBN 978-94-6343-587-1

instellingen binnen haar domein. De integrale benadering van de vraagstukken en de samenwerking tussen verschillende disciplines vormen het hart van de unieke Wageningen aanpak. 